\author{
Article type : Research Article \\ Date Received : 7/10/2021 \\ Date Accepted : : 15/11/2021 \\ Date published : 01/12/2021 \\ : www.minarjournal.com \\ http://dx.doi.org/10.47832/2717-8234.4-3.3
}

\title{
EVALUATION OF GROWTH AND SEED YIELD OF TWO CULTIVARS OF FLAX
}

\author{
Hanaa Khudhaier Mohammed Ali AL-HAIDARY ${ }^{1}$, A.F.Abed AL-KHADER², \\ B.A.SAADY ${ }^{3} \&$ B.H.JASEM 4
}

\begin{abstract}
A field experiment was carried out during winter season of 2017-2018 at at the research station of college of agricultural engineering sciences - university of Baghdad to evaluate the growth and yield of two flax cultivars. Randomized complete block design (RCBD) at three replicates. The experiment included planting the seeds of two cultivars of flax (Syrian and Egyptian). The results showed that the Syrian cv. gave the highest means of plant height $(68.77 \mathrm{~cm})$, stem diameter $(2.61 \mathrm{~mm})$, number of main branch per plant (4.85 branch . plant-1), number of capsules per plant (105.56 capsule . plant-1), number of seeds per capsule (7.93 seed . capsule-1), seed yield (1.13 ton . ha-1), biological yield (4.31 ton . ha-1) and harvest index (26.21\%). Also, the results showed that there was non-significant difference between two cultivars in weight of 1000 seeds.
\end{abstract}

Keywords: Linum Usitatissimum L, Cultivars, Vegetative Growth, Seed Yield.

\footnotetext{
${ }^{1}$ University of Baghdad, Iraq, Hanaa.khuder@coagri.uobaghdad.edu.iq, https://orcid.org/0000-00026762-8738

${ }^{2}$ University of Baghdad, Iraq

${ }^{3}$ University of Baghdad, Iraq

${ }^{4}$ University of Baghdad, Iraq
}

This article has been scanned by iThenticat No plagiarism detected

Copyright $\odot$ Published by Minar Journal, www.minarjournal.com Rimar Academy, Fatih, Istanbul, 34093 Turkey

All rights reserved 


\title{
تقييم نمو وحاصل بذور صنفين من الكتان
}

\author{
هناء خضير محمد علي الحيدري

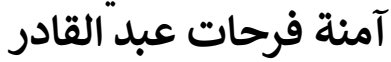 \\ بارق عبد الحق سعدي \\ باسم حامد جاسم عيدم
}

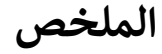

نفذت تجربة حقلية خلال الموسم الشتوي لعام 2017-2018 في المحطة البحثية

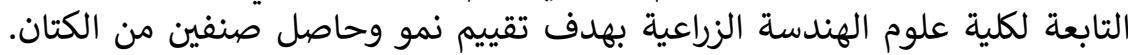

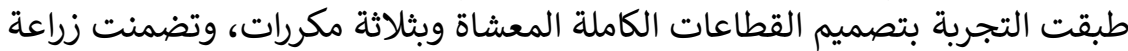

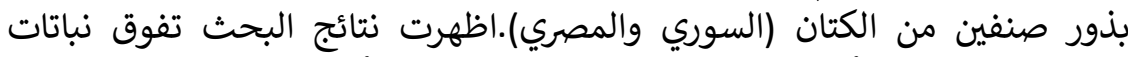

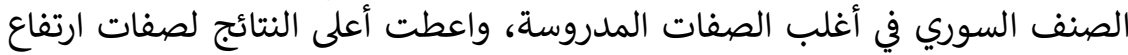
النبات (68.77 سم) وقطر الساق (2.61 ملم) وعدد الأفرع الرئيسة في النبات النيات (105.

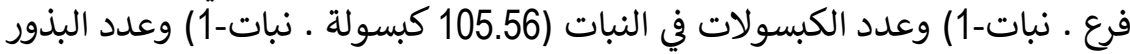

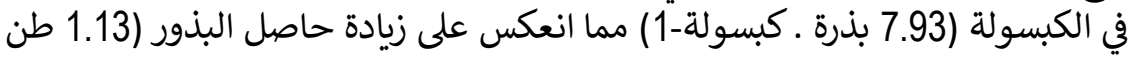

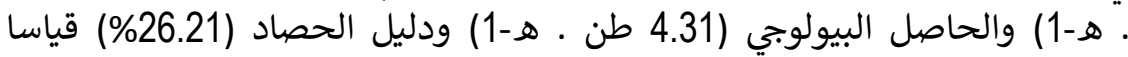

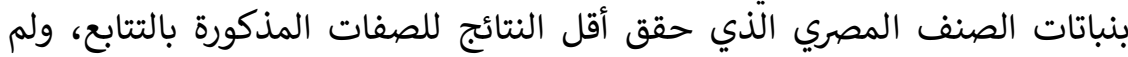

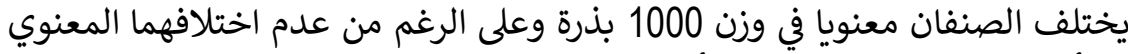

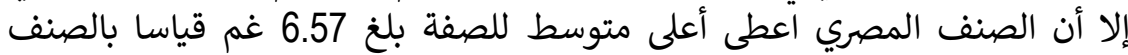

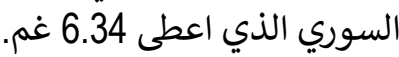
الكلمات المفتاحية: الكتان، الأصناف، النمو الخضري، حاصل البذور.
\end{abstract}

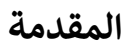

يعد الكتان (.Linum usitatissimum L.) الذي يعود إلى العائلة الكتانية Linaceae من المحاصيل المهمة

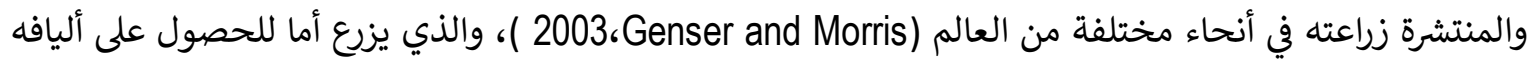

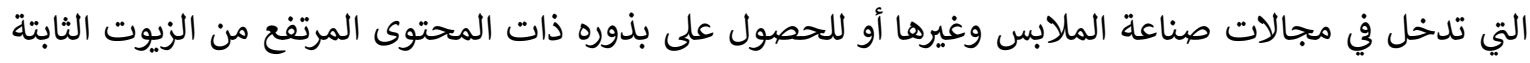

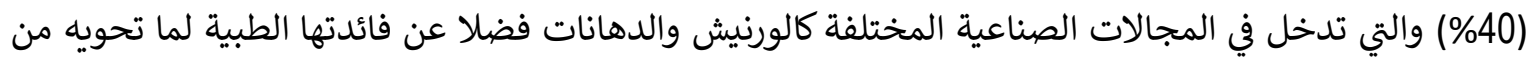

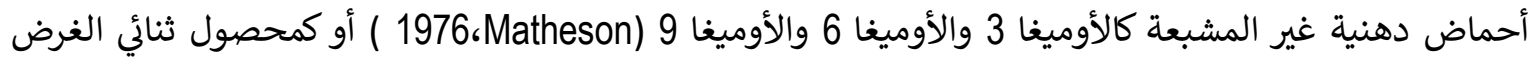

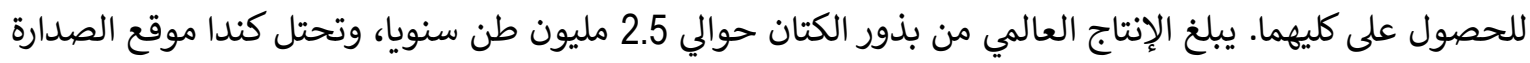

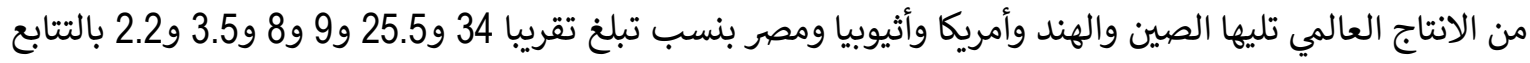

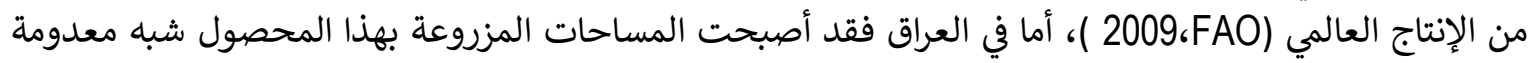

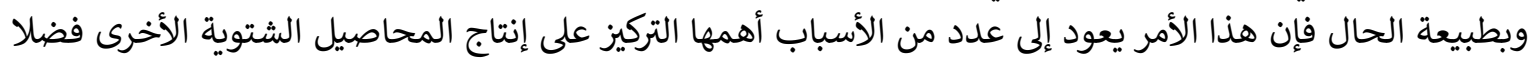

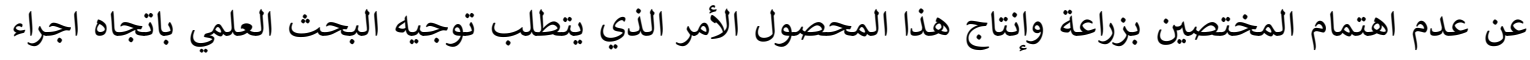

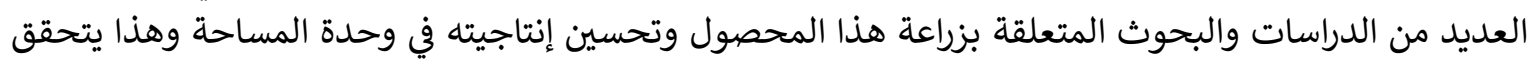

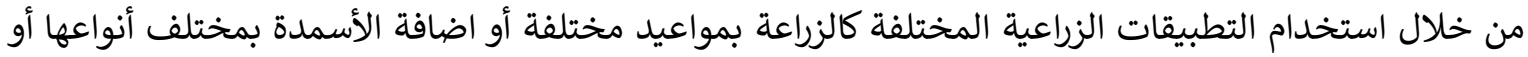

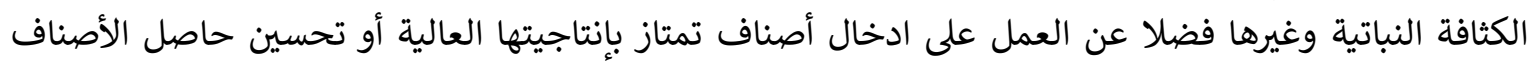

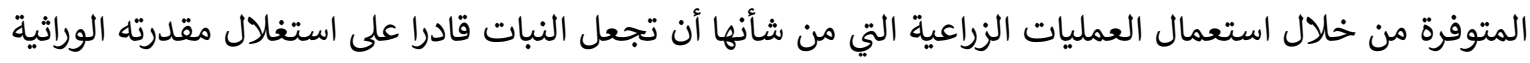

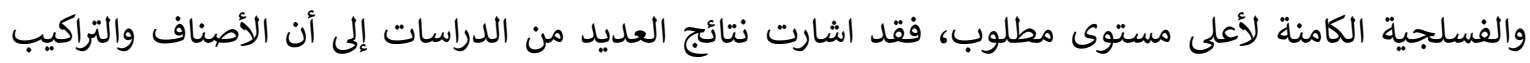

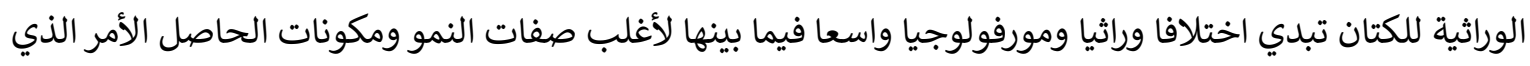

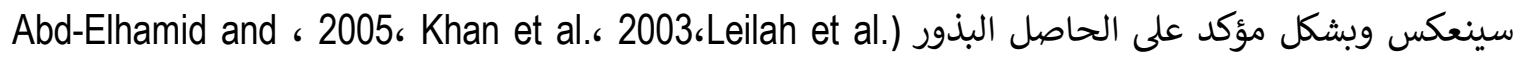


ين صئ Kumer وآخرون (2016) وجود فروق معنوية 2017، Shakya and Barwa، 2012،Sadak بين صنفي الكتان Shubhra في Swetag في صفات النمو والحاصل ومكوناته، إذ حقق الصنات الصنف

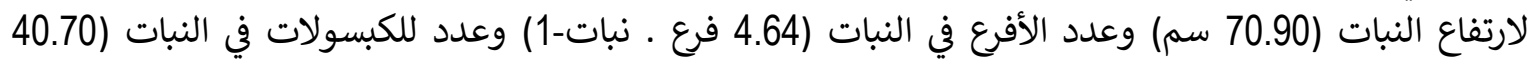

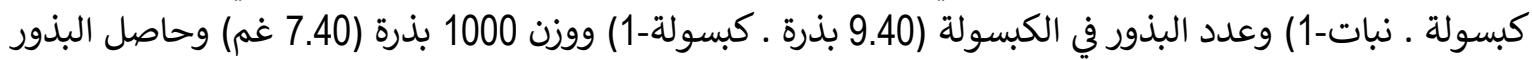

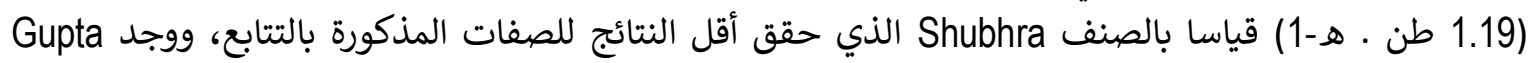

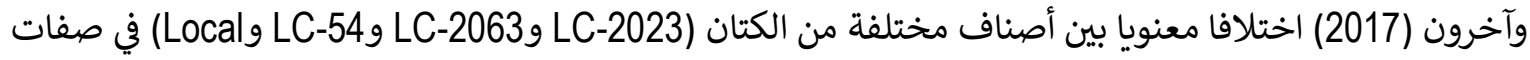

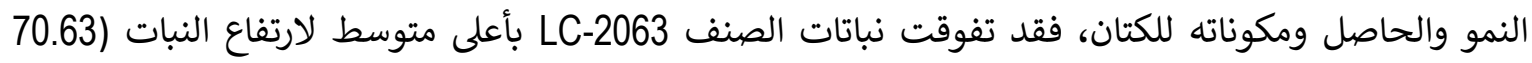

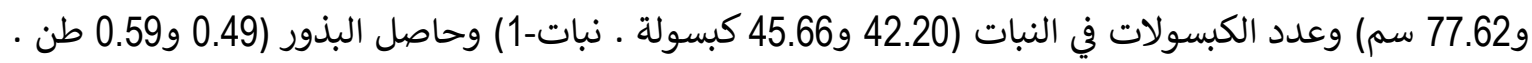

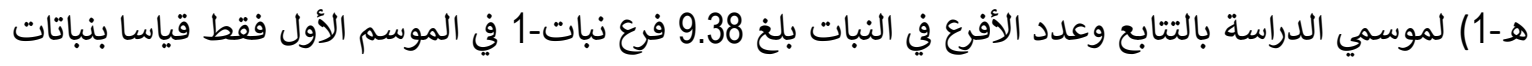

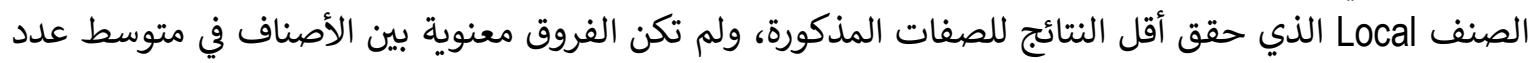

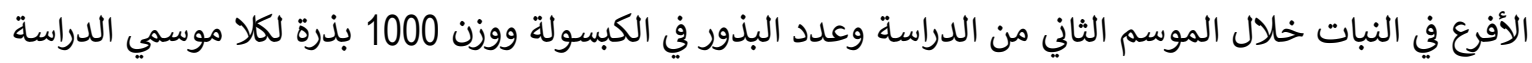

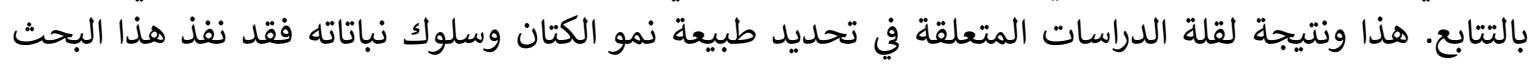
بهدف تقييم نمو ومكونات حاصل وحاصل الكتان من البذور في وحدة تحت ظريعة ندرف الكنان المنطقة الوسطى من العراق.

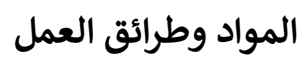

نفذت تجرية حقلية خلال الموسم الشتوي لعام 2017-2018 في المحطة البحثية التابعة لكلية علوم الهندسة

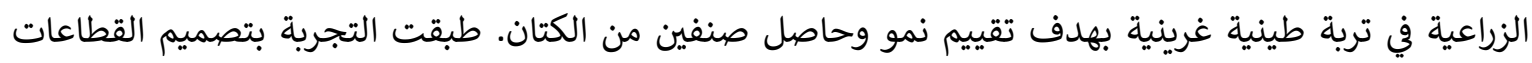

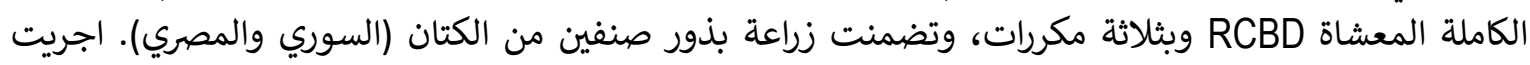

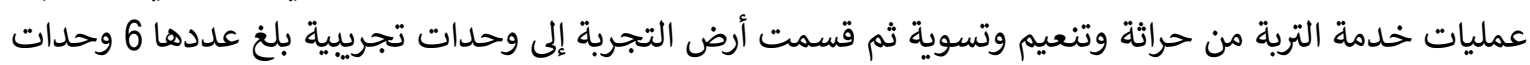

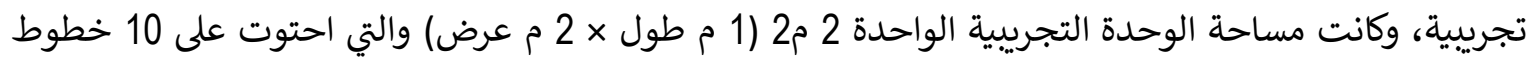

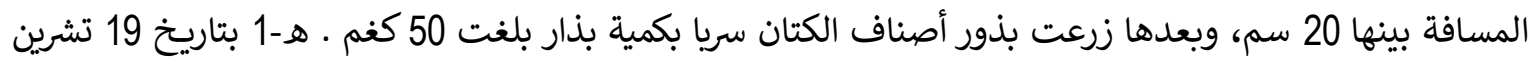

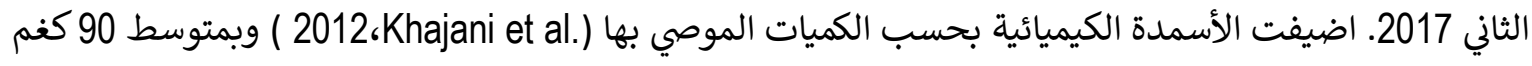

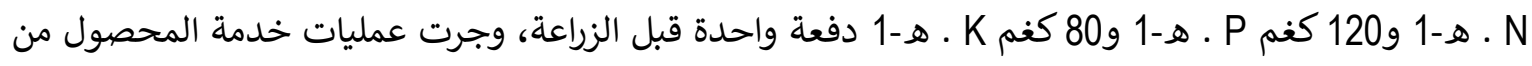

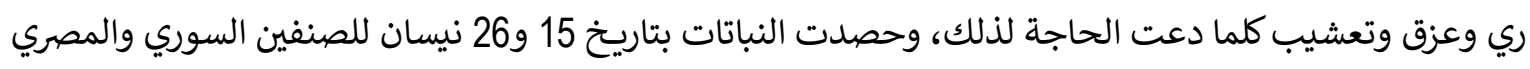

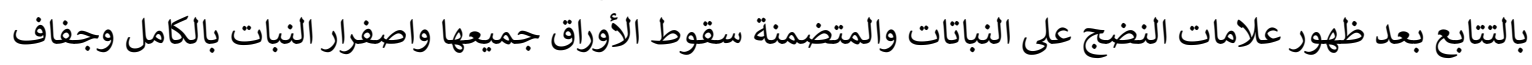

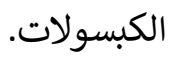

الصفات المدروسة أولا- صفات النمو الخضري 1. ارتفاع النبات (سم): تم قياس متوسط ارتفاع الساق الرئيس من سطح التربة إلى قمة النبات عند الندات مرحلة الحصاد

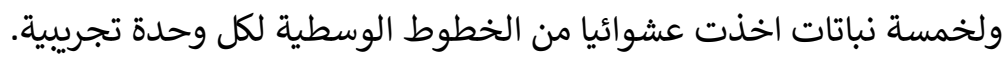

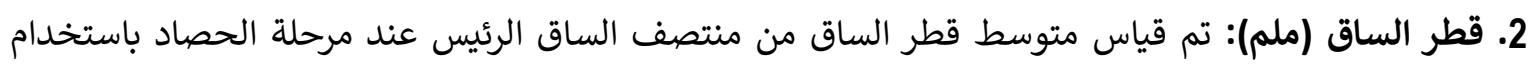

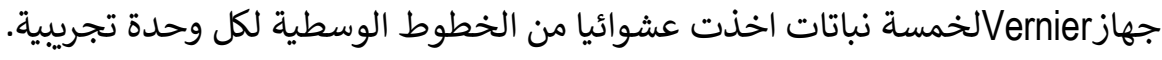

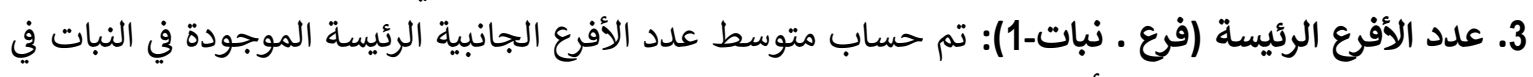
مرحلة الحصاد ولخمسة نباتات أخذت عشوائيا من الخطوط الونيات الوسطية لكل وحدة تجريبية. 
ثانيا-صفات الحاصل ومكوناته

1. عدد الكبسولات في النبات: تم حساب متوسط عدد الكبسولات في النباتات الخمسة المأخوذة عشوائيا من الخطوط الوسطية لكل وحدة تجريبية.

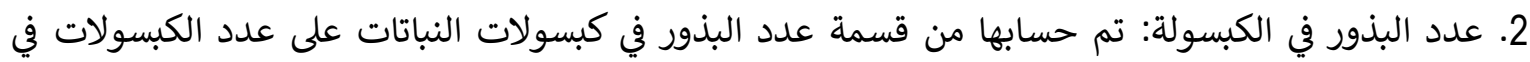

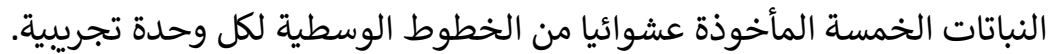

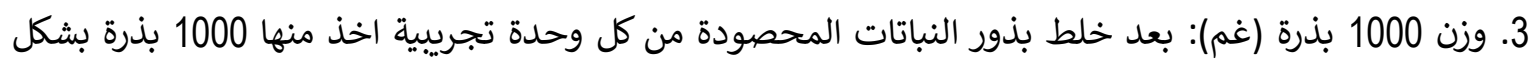
عشوائي ثم وزنت واستخرج متوسطها.

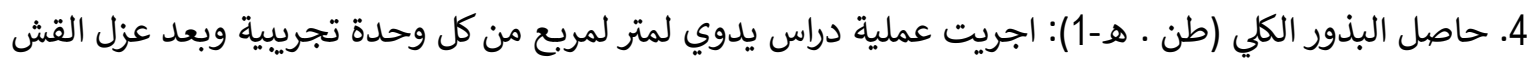

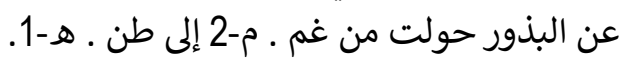

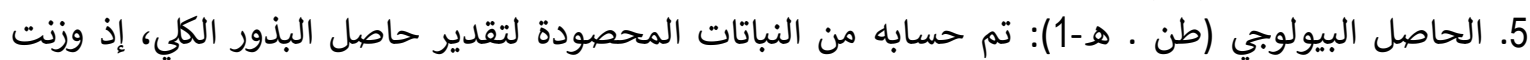

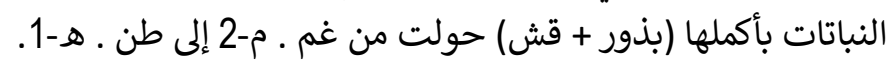

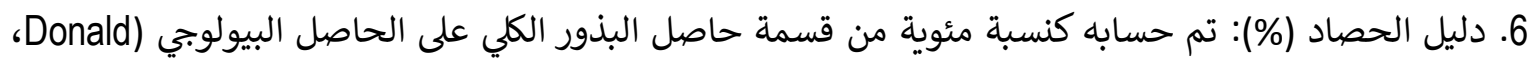
1962 حللت البيانات احصائيا للصفات المدروسة جميعها لموسم واحد حسب التراتيب والتبات والتصميم المستخدم في التجرية

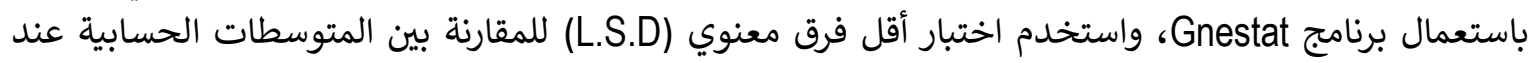

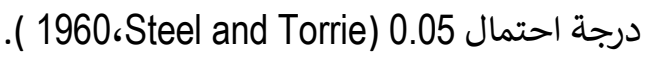

\section{النتائج والمناقشة}

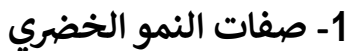

يظهر من نتائج الجدول 1 وجود اختلاف معنوي بين صنفي الكتان (السوري والمصري) في صفات النمو

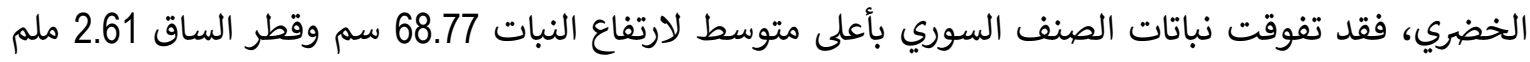

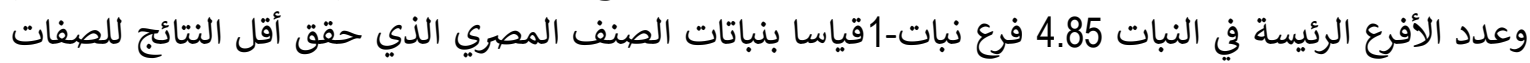

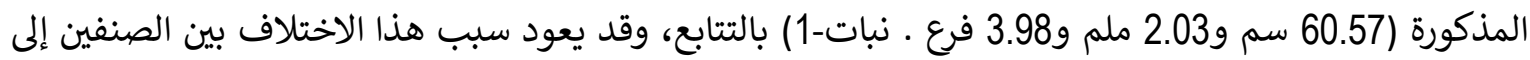

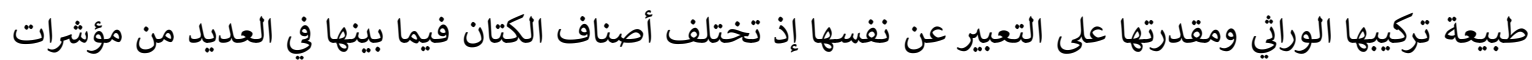

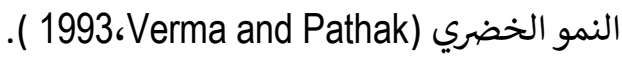
جدول 1. اختلاف الأصناف في صفات النمو الخضري (الناف

\begin{tabular}{|c|c|c|c|}
\hline عدد الأفرع الرئيسة في النبات & قطر الساق (ملم) & ارتفاع النبات (سم) & الأصناف \\
\hline 4.85 & 2.61 & 68.77 & السوري \\
\hline 3.98 & 2.03 & 60.57 & المصري \\
\hline 0.25 & 0.32 & 5.24 & L.S.D 0.05 \\
\hline
\end{tabular}

2- مكونات الحاصل والحاصل ودليل الحصاد

تشير نتائج الجدول 2 إلى وجود فروق معنوية بين صنفي الكتان (السوري والمصري) في عدد الكبسولات في

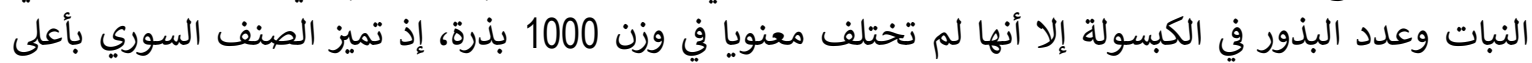

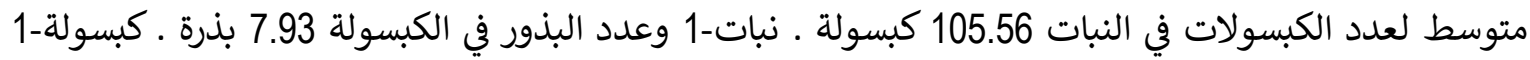

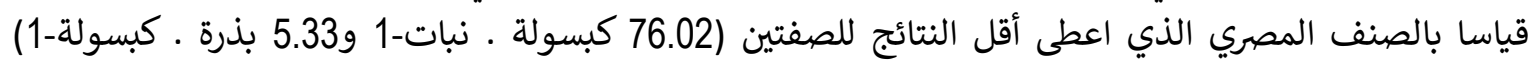

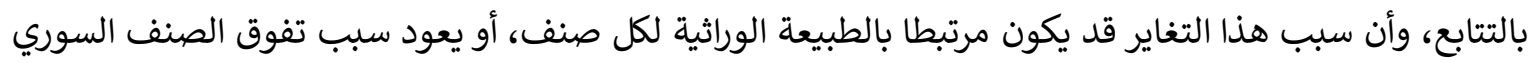

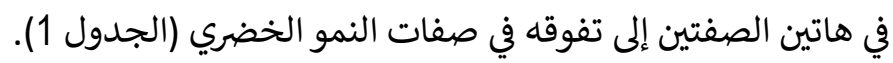
جدول 2. اختلاف الأصناف في مكونات الحاصل 


\begin{tabular}{|c|c|c|c|}
\hline 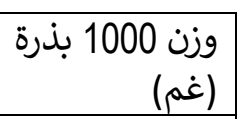 & عدد البذور في الكبسولة & عدد الكبسولات في النبات & الأصناف \\
\hline 6.34 & 7.93 & 105.56 & السوري \\
\hline 6.57 & 5.33 & 76.02 & المصري \\
\hline م.غे & 0.38 & 2.90 & L.S.D 0.05 \\
\hline
\end{tabular}

كما تبين نتائج الجدول 3 أن صنفي الكتان (السوري والمحلي) اختلفا معنويا في حاصل البذور والحاصل البيولوبي،

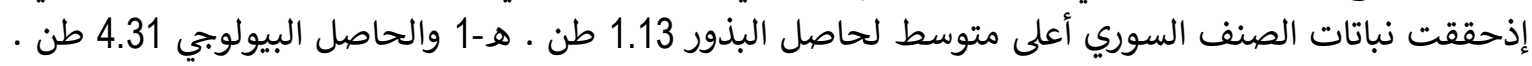

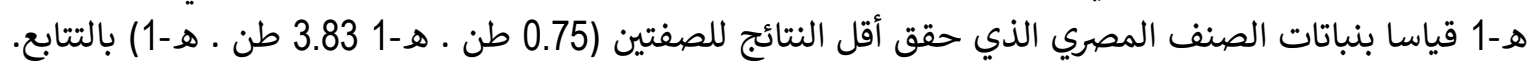

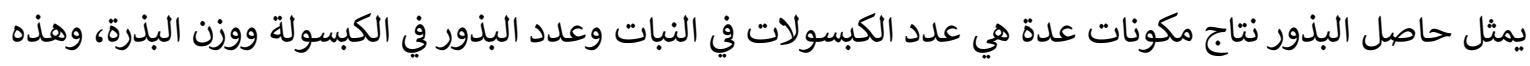

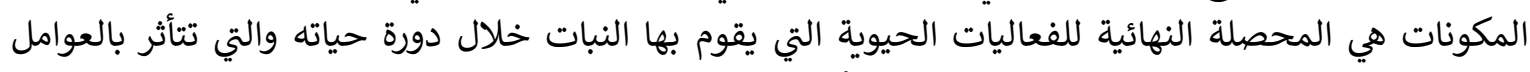

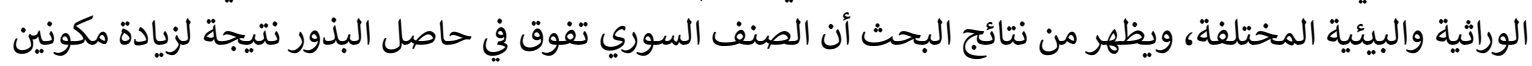

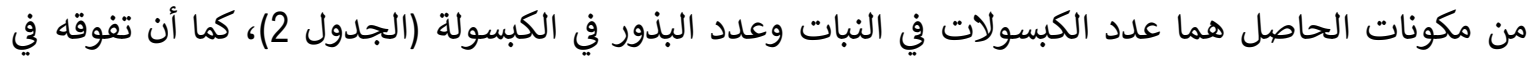

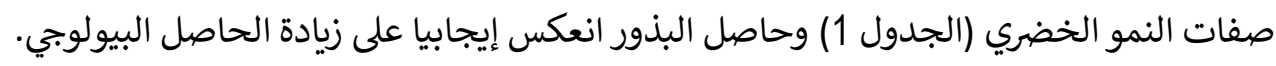

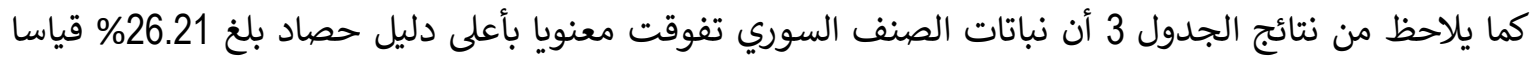

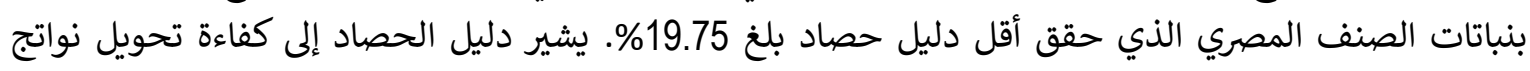

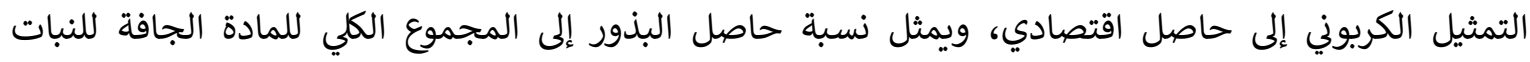

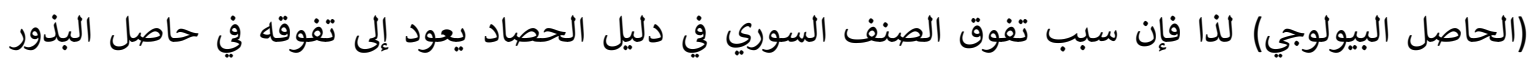
والحاصل البيولوجي.

جدول 3. اختلاف الأصناف في حاصل البذور الكلي والحاصل البيولوجي ودليل الحصاد البياد

\begin{tabular}{|c|c|c|c|}
\hline $\begin{array}{r}\text { دليل الحصاد } \\
\text { (\%) }\end{array}$ & (طن هـ-1) البيولوبي & حاصل البذور & الأصناف \\
\hline 26.21 & 4.31 & 1.13 & السوري \\
\hline 19.75 & 3.83 & 0.75 & المصري \\
\hline 3.72 & 0.42 & 0.03 & L.S.D 0.05 \\
\hline
\end{tabular}


المصادر

Abd-Elhamid، E. M. and Sadak، M. Sh. (2012). Performance of flax cultivars in response to exogenous application of salicylic acid under salinity stress. J. of Appl. Sci. Res. 8(10): 5081-5088.

Donald، C. M. (1962). In search of yield. J. Aust. Inst. Agric. Sci. 28: 495-499.

FAO. 2009. Food and Agriculture Organization of the United Nation. FAO STAT. http://llfaostat.fao.org/sit/567/fault.aspx.

Genser، A.D. and Morris، N. D. (2003). History of cultivation and uses of flaxseed. in A.D. Muir and N.D. Westcott (edrs.). Flax - The Genus Linum. Taylor and Francis. London.

Gupta، M.; Kour، S.; Gupta، V.; Bharat، R. and Sharma، C.. (2017). Effect of different doses of fertilizers on yield and NPK uptake of linseed (Linum usitatissimum L.). Bangladesh J. Bot. 46(2): 575-581.

Khajani، F. P.; Irannezhad، H.; Majidian M. and Oraki، H. (2012). Influence of different levels of nitrogen، phosphorus and potassium on yield and yield components of flax seed oil (Linum usitatissimum L.) variety Lirina. J. of Medicinal Plants Res. 6(6): 1050-1054.

Khan، M. B.; Yasir، T. A. and Aman، M. (2005). Growth and yield comparison of different linseed (Linum usitatissimum L.) genotypes planted at different row spacing.Intl. J. of Agric. ، and Biol. 7(3): 515-517.

Kumar، S.; Singh، J. K. and Vishwakarma، A. (2016). Effect of NPK levels and bio-fertilizers on quality parameters and seed yield of linseed ( arameters and seed yield of linseed (Linum usitatissimum L.) varieties under irrigated condition. Intl. Quarterly J. of Life Sci.11(2): 1339-1343.

Leilah، A. A.; El-Kassaby، A. T.; El-Hindi، M. H. and Abu-Zaid، T. A. (2003). Requirements of some flax cultivars from NPK fertilizers. Scientific J. of King Faisal Univ.، Basic.، and Appl. Sci. 4(2): 125-139.

Matheson، E. M. (1976). Vegetable Oil Seed Crops in Australia. Holt، Rinehart Press. p. 458.

Shakya، L. and Barwa، Sh. (2017). Effect of reduced doses of chemical fertilizers with dual inoculation of bio-fertilizers on linseed varieties. Intl. J. Innovative Res. Sci.، Engineering and Technol. 6(7): 14123-14129.

Steel، R. G. and Torrie، Y. H. (1960). Principles and Procedures of Statistics. Mc Grow - Hill Book Co. Inc. New York. pp. 480.

Verma، K. P. and Pathak، P. K. (1993). Response of linseed (Linum usitatissmum L.) Varieties to different dates of sowing. Indian J. of Agron.، 38(1): 160-163. 